\title{
Being a front-line dentist during the Covid- 19 pandemic: a literature review
}

Hamid Reza Fallahi ${ }^{1,2}$, Seied Omid Keyhan ${ }^{3,45^{*}}$, Dana Zandian ${ }^{1,2}$, Seong-Gon Kim ${ }^{6,7^{*}}$ and Behzad Cheshmi ${ }^{8}$

\begin{abstract}
Coronavirus is an enveloped virus with positive-sense single-stranded RNA. Coronavirus infection in humans mainly affects the upper respiratory tract and to a lesser extent the gastrointestinal tract. Clinical symptoms of coronavirus infections can range from relatively mild (similar to the common cold) to severe (bronchitis, pneumonia, and renal involvement). The disease caused by the 2019 novel coronavirus (2019-nCoV) was called Covid-19 by the World Health Organization in February 2020. Face-to-face communication and consistent exposure to body fluids such as blood and saliva predispose dental care workers at serious risk for 2019-nCoV infection. As demonstrated by the recent coronavirus outbreak, information is not enough. During dental practice, blood and saliva can be scattered. Accordingly, dental practice can be a potential risk for dental staff, and there is a high risk of cross-infection. This article addresses all information collected to date on the virus, in accordance with the guidelines of international health care institutions, and provides a comprehensive protocol for managing possible exposure to patients or those suspected of having coronavirus.
\end{abstract}

Keywords: Coronavirus, Covid-19, 2019-nCoV, Dental care, Dentistry

\section{Background}

Since the first reported case in Wuhan, China, in December 2019, coronavirus disease-19 (Covid-19) has widely spread to Japan, Korea, Iran, and many European countries [1]. The World Health Organization (WHO) declared a pandemic in March 2020. As saliva is a main tool of spread, dentists are in danger of contracting Covid-19. Although the exact nature of this disease must be clarified in detailed studies, current knowledge of coronavirus infection should be shared without any restrictions.

This article was written by an Iranian team of oral and maxillofacial surgeons. As Iran has many Covid-19 patients, they have significant experience with this disease. Maxillofacial Plastic and Reconstructive Surgery is an open-access journal, and this type of important information can be shared via our publication platform without restrictions.

\footnotetext{
* Correspondence: keyhanomid@ymail.com; kimsg@gwnu.ac.kr

${ }^{3}$ CMFRC, National Advance Center for Craniomaxillofacial Reconstruction,

Tehran, Iran

${ }^{6}$ Department of Oral and Maxillofacial Surgery, College of Dentistry,

Gangneung-Wonju National University, Gangneung 28644, Republic of Korea Full list of author information is available at the end of the article
}

\section{Coronaviruses}

Coronaviruses are enveloped viruses with a positivesense single-stranded RNA genome. Their helical symmetry nucleocapsid is approximately $26-32 \mathrm{~kb}$ in size, making it the largest investigated genome among RNA viruses [2,3]. Coronaviruses have a fundamental resemblance in their organization and genome expression [4]. Previously, it was thought that coronaviruses only cause enzootic infections in a number of animals, including certain birds and mammals, but recent findings indicate that a variety of these viruses, including antigenic groups 1 (229E and NL63), antigenic groups 2 (OC43), and HKU1, can infect humans [5, 6]. These viruses often lead to upper respiratory tract infection, frequently resulting in common cold symptoms. Three specific strains of these viruses that are of zoonotic origin, including severe acute respiratory syndrome coronavirus (SARS-CoV), Middle East respiratory syndrome coronavirus (MERS$\mathrm{CoV})$, and 2019 novel coronavirus (2019-nCoV), have recently caused lethal infections in humans $[4,6,7]$.

Coronavirus infections in humans mainly affect the upper respiratory tract and to a lesser extent the gastrointestinal 
tract. Manifestations of coronavirus infections can range from relatively mild (similar to the common cold) to severe (bronchitis, pneumonia, and renal involvement) [8] (Table 1).

\section{Pathogenesis}

The ability to infect humans is mainly due to the infection of peridomestic animals, which are considered intermediate hosts, nurturing recombination and mutation events as well as the development of genetic diversity among coronaviruses [29]. Studies have suggested that the spike glycoprotein (S glycoprotein) plays an important role in host range restriction by attaching virions to the host cell membrane [30]. Generally, coronaviruses primarily replicate in the respiratory and intestinal epithelial cells and subsequently cause cytopathic alterations [31].

\section{Covid-19}

Since December 2019, numerous unexplained cases of pneumonia have been reported in China. The disease caused by $2019-\mathrm{nCoV}$ was called Covid-19 by the WHO in February 2020 [32]. Limiting the exposure of suspicious cases to the rest of society could be an effective strategy in the early outbreak phases. However, the subsequent worldwide virus spread and person-to-person transmission made the situation more complex and uncontrollable [33].

No detailed studies have been conducted to expound the pathogenicity of $2019-\mathrm{nCoV}$ on a molecular scale. However, exploratory data established via whole-genome sequencing and subsequent bioinformatics analyses revealed that $2019-\mathrm{nCoV}$ is phylogenetically related to SARS-CoV that was isolated for the first time in Chinese horseshoe bats between 2015 and 2017 [34-36].

\section{Clinical manifestations}

To a large extent, the clinical similarities of 2019-nCoV infection with SARS-CoV infection are substantial. The incubation period of 2019-nCov has been estimated to be 1-14 days, and it has been shown that asymptomatic individuals may also be involved in the spread of this virus [26-28]. Since the possibility of the transmission from asymptomatic carriers has been raised currently, checking body temperature only may not be enough to screen asymptomatic carriers. According to a recent report, temperature-based screening in the airport can detect only $46 \%$ of $2019-\mathrm{nCoV}$ carriers and the others were found during the self-isolation period after immigration [29]. To suppress the disease spread, a wide range of laboratory tests for immigrants and general population seems to be necessary. However, the infection rate from asymptomatic carriers has not been clarified until now. The primary non-specific reported symptoms of 2019-nCoV infection at the prodromal phase are malaise, fever, and dry cough. The most commonly reported signs and symptoms are fever (98\%), cough (76\%), dyspnea (55\%), and myalgia or fatigue $(44 \%)[25,26]$. Unlike patients with other human coronavirus infections (such as SARS-CoV), upper respiratory tract and intestinal manifestations such as sore throat, rhinorrhea, and diarrhea in those with 2019$\mathrm{nCoV}$ infection are infrequent $[15,25,26]$ (Fig. 1).

\section{Patient characteristics}

The patient mean age is generally between 49 and 61 years. Studies have shown that males are more likely to have this infection [25, 26, 37]. The lack of serious illness in youngsters is a characteristic of SARS-CoV infection, which is similarly observed in 2019-nCoV infection [32]. Increased exposures to 2019-nCoV due to occupational requirements, for instance health care workers, maybe another factor contributing to the higher risk of infection.

\section{Diagnosis}

Following the outbreak, the full 2019-nCoV genomic sequence was released in public databases [38]. This facilitates the way for further PCR assays for virus

Table 1 Comparison of clinical symptoms and incubation time of human coronaviruses [4]

\begin{tabular}{|c|c|c|c|}
\hline Human coronaviruses & Clinical symptoms & Incubation period & Refs. \\
\hline $229 E$ & $\begin{array}{l}\text { General malaise, headache, nasal discharge, sneezing, sore throat, fever and cough } \\
\text { (10-20\% of patients) }\end{array}$ & 2-5 days & [9-11] \\
\hline OC43 & $\begin{array}{l}\text { General malaise, headache, nasal discharge, sneezing, sore throat, fever and cough } \\
\text { (10-20\% of patients) }\end{array}$ & $2-5$ days & {$[9,11-13]$} \\
\hline NL63 & Cough, rhinorrhea, tachypnea, fever, hypoxia, obstructive laryngitis (croup) & $2-4$ days & {$[14-19]$} \\
\hline HKU1 & Fever, running nose, cough, dyspnea & $2-4$ days & {$[20-22]$} \\
\hline SARS-COV & $\begin{array}{l}\text { Fever, myalgia, headache, malaise, chills, non-productive cough, dyspnea, respiratory } \\
\text { distress, diarrhea (30-40\% of patients) }\end{array}$ & 2-11 days & {$[14-19]$} \\
\hline MERS-COV & $\begin{array}{l}\text { Fever, cough, chills, sore throat, myalgia, arthralgia, dyspnea, pneumonia, diarrhea } \\
\text { and vomiting (one third of patients), acute renal impairment }\end{array}$ & 2-13 days & {$[15,23,24]$} \\
\hline 2019-nCoV & Malaise, fever, dry cough, cough, dyspnea, myalgia, fatigue & $1-14$ days & {$[25-28]$} \\
\hline
\end{tabular}



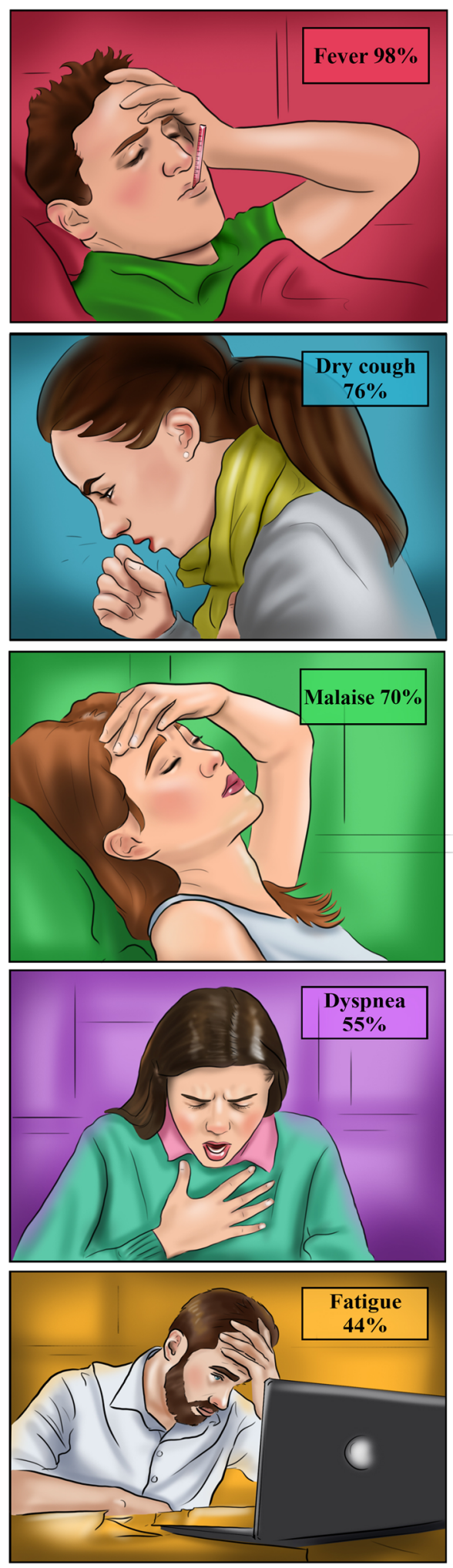

Fig. 1 Signs and symptoms of Covid-19 detection. The WHO recommendations for outpatient cases and patients with more critical conditions respectively include rapid collection and nucleic acid amplification testing (NAAT) of respiratory samples including nasopharyngeal and oropharyngeal swabs as well as sputum and/or endotracheal aspirate or bronchoalveolar lavage [39]. Table 2 presents recommended instructions that all practitioners in the field of dental care, including dentists, assistants, and others, should consider when treating patients or those suspected of having coronavirus.

\section{Protocol}

Figure 2 shows a protocol that can organize our approach to managing suspected or infected patients. The purpose of this protocol is to protect the entire dental care team, prevent any cross-infection in the office, inform health authorities active in the field of controlling and managing the disease, and ultimately provide the optimal medical and dental care for patients affected by the virus according to the $\mathrm{CDC}$ and the ADA guidelines.

\section{Transmission dynamics}

The two main routes known for 2019-nCoV transmission include (1) direct transmission (through coughing, sneezing, and inhalation of droplets) and (2) contact transmission (through contact with nasal, oral, and ocular mucosa) [43]. Typical clinical manifestations of Covid-2019 do not comprise ocular symptoms. However, conjunctival sample analysis has revealed that the transmission of 2019-nCoV is not limited to the respiratory tract route [26], but ocular exposure is also an effective method of virus transmission [44]. Moreover, studies have revealed that via direct/indirect contact or course and/or droplets, respiratory viruses such as 2019-nCoV may be transmitted from human to human. Studies have also shown direct and indirect transmission of 2019-nCoV through saliva [45].

For a comprehensive understanding of the transmission dynamics of 2019-nCoV, it is also important to know that this virus is also transmissible through asymptomatic patients [34]. The remarkable feature of $2019-\mathrm{nCoV}$ is that its RNA is detectable via quantitative reverse transcriptase polymerase chain reaction (qRT-PCR) in stool samples after the first week of infection [46]. However, the aerosol and fecal-oral transmission routes, which carry more public concern, still need further investigation and confirmation [47] (Fig. 3).

\section{Transmission dynamics in dentistry practice}

New evidence suggests that 2019-nCoV may be transmitted directly from human to human via respiratory secretion containing droplets [44, 48]. Virus transmission through contact and fomites is also likely [44, 48]. To et al. [44] reported that using the viral culture 
Table 2 Standard precautions based on CDC and ADA guidelines for dentists on the coronavirus disease [40-42]

\begin{tabular}{ll}
\hline Postponing & $\begin{array}{l}\text { Following the announcement of disease outbreak by international or local authorities, dentists can play a } \\
\text { significant role in disrupting the transmission chain, thereby reducing the incidence of the disease by simply } \\
\text { postponing all non-emergency dental care for all patients. }\end{array}$ \\
\hline Where to treat & $\begin{array}{l}\text { All dental care should be provided in an outpatient dental setting with a minimum of six air changes per hour, } \\
\text { such as a hospital with dental care services or customized clinics equipped for Covid-19 patients. }\end{array}$ \\
Symptoms and history & $\begin{array}{l}\text { Primary non-specific reported symptoms of 2019-nCov infection at the prodromal phase are malaise, fever, and } \\
\text { dry cough. The most commonly reported signs and symptoms are fever (98\%), cough (76\%), dyspnea (55\%), and } \\
\text { myalgia or fatigue (44\%). }\end{array}$
\end{tabular}

They also may have traveled to one of the countries considered disease hotspots in the prior 14 days or have encountered people from those countries or people who have traveled to those countries.

Some patients may be asymptomatic or have unexpected symptoms such as diarrhea.

How long?

Preparations and arrangement

Transmission prevention consideration

Guidelines updates

Health care workers
Since it is not possible to know the etiology of each patient's illness, it is crucial to follow the guidelines and precautions at all times during the disease outbreak.

Be alert, identify patients with respiratory illnesses, and provide them a disposable surgical face mask. Isolate them in a room with the door closed. Limit their direct contact with others. Isolated patients must wear masks outside their room.

Isolate suspected patients before and during care to minimize their direct contact with other patients and staff and immediately report any cases to local and state public health authorities.

To prevent 2019-nCoV transmission, dental practices should adhere to the infection control protocol, including hand hygiene, providing tissues and no-touch receptacles, and providing face masks for coughing patients.

Dental health care personnel should wear white coats, gowns, head caps, goggles, face shields, masks, latex gloves, and impermeable shoe covers to prevent exposure.

Disposable masks should be substituted between patients or even during treatment if they get wet.

Since Covid-19 recommendations may change rapidly with increasing information about the disease, the ADA recommends checking for updates on the CDC's coronavirus infection control web page for health care professionals.

The CDC strongly recommends that all health care staff, including dentists and personnel, should receive the flu vaccine and that staff with influenza must not report to work. method, they detected 2019-nCoV in infected individuals' saliva samples. In addition, 2019-nCov invades the cells through the angiotensin-converting enzyme 2 (ACE2) receptor in the same way as the SARS coronavirus [49]. Since 2019-nCoV effectively uses ACE2 receptor for cell invasion, it can promote human-tohuman transmission [50]. ACE2+ cells are abundantly present all over the respiratory tract. ACE2+ epithelial cells present in the salivary glands were considered one of the main targets of SARS coronavirus infection. Similarly, 2019-nCoV may also use the same mechanism to induce infection, although definitive judgment regarding this issue needs further study [51].

Due to close face-to-face contact with patients and frequent utilization of sharp devices, dental personnel are repeatedly exposed to respiratory tract secretions, blood, saliva, and other contaminated body fluids and are always at risk for 2019-nCoV infection. 2019-nCoV transmission in dental settings occurs through four major routes: (1) direct exposure to respiratory secretions containing droplets, blood, saliva, or other patient materials; (2) indirect contact with contaminated surfaces and/or instruments; (3) inhalation of suspending airborne viruses; and (4) mucosal (nasal, oral, and conjunctival) contact with infection-containing droplets and aerosols that are propelled by coughing and talking without a mask [51-55] (Fig. 4).

The most important concern in dental clinics is the transmission of 2019-nCoV via droplets and aerosol because, despite all of the precautions taken, it is almost impossible to reduce droplet and aerosol production to zero during dental procedures [54]. Dental handpieces utilize high-speed gas to rotate with running water, which leads to the generation of a considerable amount of droplets and aerosol mixed with patients' saliva and/ or blood [55]. Therefore, it can be deduced that 2019$\mathrm{nCoV}$ is capable of transmitting through dental practice; this transmission can be from patients to clinic staff or other patients at the clinic [56].

Research has shown that coronaviruses can remain on metal, glass, and plastic surfaces for several days [52, 57]. Therefore, as surfaces in dental clinics serve as venues for droplets and aerosol mixed with patients' saliva and/ or blood, they can effectively help spread infection. Coronaviruses can actively maintain their virulence at room temperature from $2 \mathrm{~h}$ up to 9 days. Their activity at $50 \%$ humidity was significantly higher than $30 \%$. Therefore, in the dental environment, it seems that keeping surfaces clean and dry will play a significant role in preventing 2019-nCoV transmission [52]. 
(1) Following the announcement of the disease outbreak by international or local authorities, the dentist can play a significant role in disrupting the transmission
chain and thereby reducing the incidence of the disease by just by postponing all non-emergent dental care for all individuals.
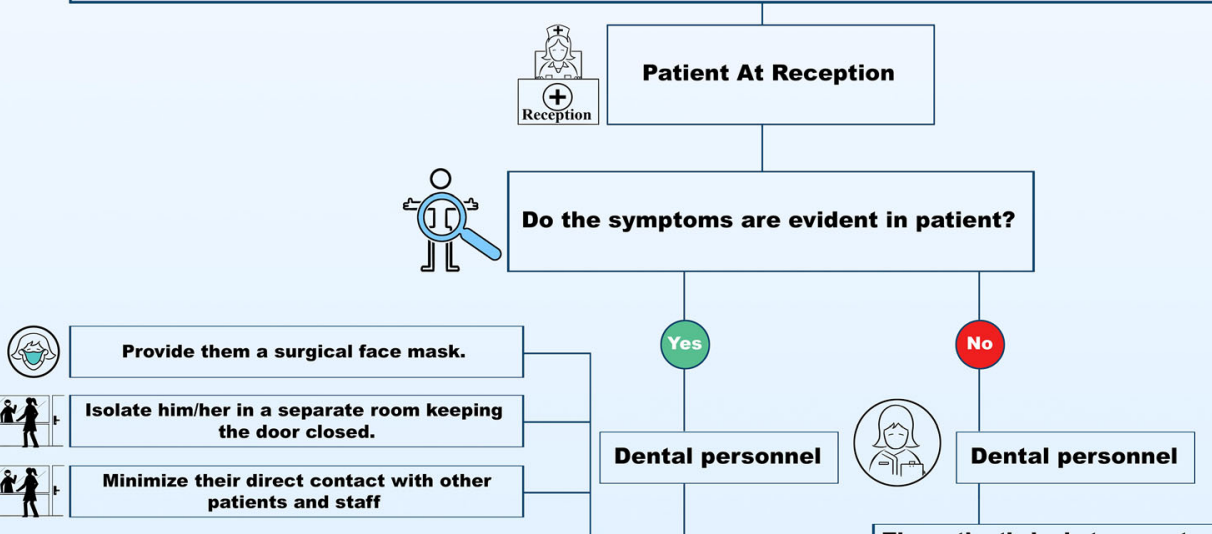 Patients should be required to wear masks
outside the room. In cases of non-emergent issues, the dentist Should defer the treatment for at least 14 days. The patient should be mandated for self-quaran-
tine at home and report any flu-like symptoms to
the local health authority.
the at home and report any 1 Emergent dental care should be accomplished at an outpatient dental setting where there is a minimum of six air changes per hour, such as a clinics equipped for COVID-19 medical care.

\section{Dental personnel should inform the dentist}

The patient's body temperature should be measured using a contact-free forehead thermometer.

The patient should reply the following questions: 1. Have you been feeling fever now or during the past 14 days?

2. Have you had any respiratory problems during the past 14 days, such as cough or shortness of breath?

3. Have you traveled to one of the countries considered as disease hotspots in the last 14 days or have you encountered people from those countries or people who have traveled to those countries?

4. Have you encountered a patient with documented COVD-19 in the last 14 days?

5. Have you encountered any person with flu-like symptoms in the last 14 days?

6. Have you recently attended a meeting with many people?

Inform the dentist about the patient's responses The dentist should examine the patient in

In cases of non-emergent issues, the dentist should defer the treatment for at least 14 days. The patient should be mandated for self-quarantine at home and report any flu-like symptoms to the local (i) health authority

Emergent treatments should be accomplished at an outpatient dental setting where there is a minimum of six air changes per hour, such as a hospital with dental care services or special clinics .equipped for COVID-19 medical care

In cases of non-emergent issues, the dentist should defer the treatment for at least 14 days. The patient should be mandated for self-quarantine at home and report any flu-like symptoms to the local health authority.

Emergent dental care should be accomplished at an outpatient dental setting where there is a minimum of six air changes per hour, such as a hospital with dental care services or special clinics equipped for COVID-19 medical care.

The patient must be reported to the local or public health authorities.

With extra-protection measures, the dentist can treat the patient just for emergent issues, avoiding any spatter or aerosol-generating procedures as much as possible.

In cases of non-emergent issues, the dentist should defer the treatment for at least 14 days. The patient should be mandated for self-quarantine at home and report any flu-like symptoms to the local health authority.

Emergent dental care should be accomplished at an outpatient dental setting where there is a mini-

11 mum of six air changes per hour, such as a hospital with dental care services or special clinics equipped for COVID-19 medical care.

The patient must be reported to the local or public health authorities.
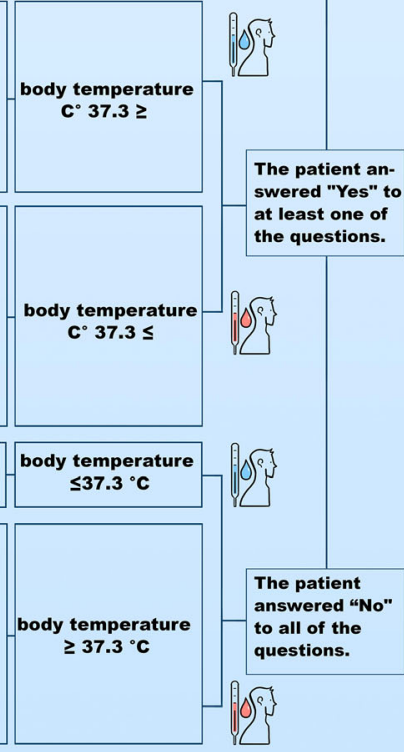

Fig. 2 Protocol for the management of patients during the Covid-19 pandemic 


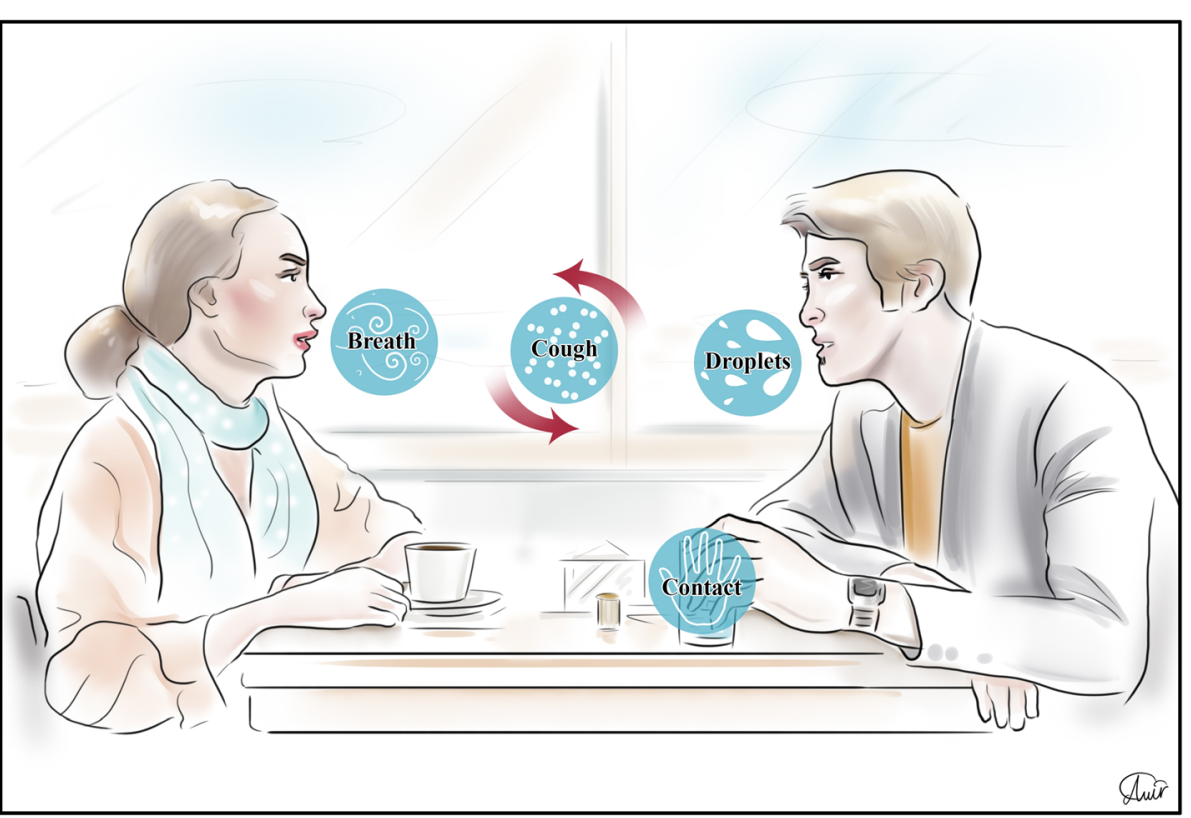

Fig. 3 Common transmission routes of the 2019-nCoV

\section{Infection control}

Since the fecal-oral route is considered one of the 2019$\mathrm{nCoV}$ transmission routes, attention to hand hygiene before, during, and after dental practice is important. Dentists should exercise extreme caution to avoid contact with their own facial mucosal surfaces including their eyes, mouth, and nose. Since transmission of airborne droplet is considered one of the main routes of infection spread, application of personal protective equipment such as masks, protective goggles, gowns, helmet, gloves, caps, face shields, and shoe covers is strongly recommended for all health care personnel.

Covid-19 patients should not be treated in a regular dental care setting without special considerations. Unexpected circumstances may occur when the dentist cannot delay treatment or refer the patient to the appropriate

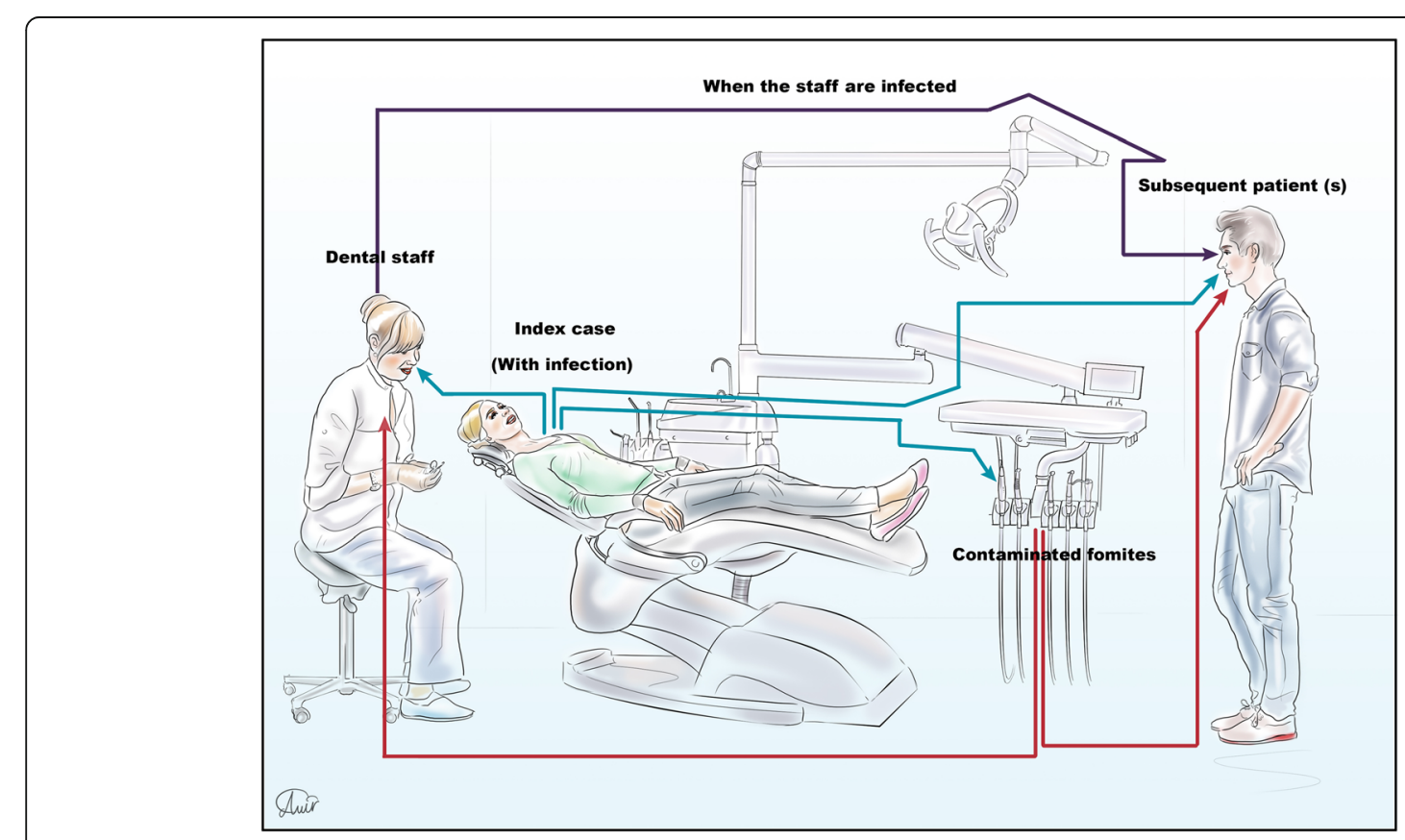

Fig. 4 2019-nCoV transmission dynamics in dental care settings 
medical institution. Under such circumstances, special protective clothing such as hazardous materials (hazmat) suits are required. If hazmat suits are not available, white coats, gowns, head caps, protective eyewear, face shields, masks, latex gloves, and virus-proof shoe covers should be used [56].

\section{Mouth rinses}

The effect of chlorhexidine, which is commonly used for pre-procedural mouth washing in dental practice, has not yet been demonstrated to be capable of eliminating 2019$\mathrm{nCoV}$. However, oxidative agents containing mouth rinses with $1 \%$ hydrogen peroxide or $0.2 \%$ povidone-iodine are recommended. Pre-procedural use of mouthwash, especially in cases of inability to use a rubber dam, can significantly reduce the microbial load of oral cavity fluids [58].

\section{Rubber dam isolation}

Using rubber dams due to the creation of a barrier in the oral cavity effectively reduces the generation of droplets and aerosol mixed with patient saliva and/or blood in $1 \mathrm{~m}$ diameter of the surgical field by 70\% [59]. Following the placement of the dam, extra high-volume suction is also required for maximum prevention of aerosol and spatter from spreading [60]. If it is not possible to use rubber dams for any reason, manual tools such as Carisolvs or hand scalers are preferable.

\section{Anti-retraction handpiece}

Throughout the COVID-19 pandemic, the use of any dental handpieces that do not have an anti-retraction function should be avoided. For emergency treatment, anti-retraction handpieces designed with anti-retractive valves can play an effective role in preventing the diffusion and dispersion of droplets and aerosol $[60,61]$.

\section{Appropriate disinfectants}

Since there is still little information available regarding 2019-nCoV, relatively similar genetic features between 2019-nCoV and SARS-CoV indicate that the novel coronavirus can be vulnerable to disinfectants such as sodium hypochlorite $(1000 \mathrm{ppm}$ or $0.1 \%$ for surfaces and $10,000 \mathrm{ppm}$ or $1 \%$ for blood spills), $0.5 \%$ hydrogen peroxide, $62-71 \%$ ethanol, and phenolic and quaternary ammonium compounds if utilized in accordance with the manufacturer's instructions. Studies show that other biocidal agents such as $0.05-0.2 \%$ benzalkonium chloride or $0.02 \%$ chlorhexidine digluconate probably have lower efficiency. In addition to the type of disinfectant, paying attention to other factors such as the duration of use, dilution rate, and especially the expiration time following the preparation of the solution according to the manufacturer's instructions is also crucial.

\section{Management of medical waste}

Prior to any inappropriate accumulation, dental office waste should be routinely transported to the institution's temporary storage facility. Reusable tools and equipment must be properly pre-treated, cleaned, sterilized, and properly stored until the next use. Dental waste resulting from the treatment of suspected or confirmed 2019$\mathrm{nCoV}$ patients is considered medically infectious waste that must be strictly disposed of in accordance with the official instructions using double-layer yellow medical waste package bags and "gooseneck" ligation.

\section{Conclusion}

Following the announcement of the disease outbreak by international or local authorities, dentists can play a significant role in disrupting the transmission chain, thereby reducing the incidence of disease by simply postponing all non-emergency dental care for all patients. Dental professionals must be fully aware of $2019-\mathrm{nCoV}$ spreading modalities, how to identify patients with this infection, and, most importantly, self-protection considerations. The effect of chlorhexidine, which is commonly used for preprocedural mouth washing in dental practice, has not yet been demonstrated to be capable of eliminating 2019$\mathrm{nCoV}$. However, the prescription of oxidative agents containing mouth rinses such as $1 \%$ hydrogen peroxide or $0.2 \%$ povidone is recommended. A higher rate of virus exposure because of occupational commitments in health care workers is considered a key factor associated with the increased risk of infection.

\section{Abbreviations \\ Covid-19: Coronavirus disease-19; WHO: World Health Organization; SARS- CoV: Severe acute respiratory syndrome coronavirus; MERS-CoV: Middle East respiratory syndrome coronavirus; 2019-nCoV: 2019 novel coronavirus; qRT- PCR: Quantitative reverse transcriptase polymerase chain reaction; ACE2: Angiotensin-converting enzyme 2; NAAT: Nucleic acid amplification testing}

\section{Acknowledgements \\ Prof. Esmaeil Yazdi passed away due to coronavirus infection few days ago. He was one of the Iranian Society of OMFS founder 60 years ago. The authors send sincere condolence to his family and colleagues. The authors also appreciate his great contribution on the progress of maxillofacial surgery.}

\section{Authors' contributions}

The article was written by HRF and BC. DZ collected the data. Illustrations were drawn by SOK and BC. SOK and KSG corrected the article and performed the critical review. The authors read and approved the final manuscript.

\section{Funding}

Not applicable.

\section{Availability of data and materials Not applicable.}

Ethics approval and consent to participate Not applicable. 


\section{Consent for publication}

Not applicable.

\section{Competing interests}

The authors declare that the authors have no competing interests as defined by Nature Research or other interests that might be perceived to influence the results and/or discussion reported in this paper.

\section{Author details}

${ }^{1}$ School of Advanced Technologies in Medicine, Shahid Beheshti University of Medical Sciences, Tehran, Iran. ${ }^{2}$ Dental Research Center, Research Institute of Dental Sciences, Shahid Beheshti University of Medical Sciences, Tehran, Iran. ${ }^{3} \mathrm{CMFRC}$, National Advance Center for Craniomaxillofacial Reconstruction, Tehran, Iran. ${ }^{4}$ Craniomaxillofacial Research Center, Tehran University of Medical Sciences, Tehran, Iran. ${ }^{5}$ Bahar building, Shahid Nuranian Alley, Saadat Abad, Isfahan, Iran. ${ }^{6}$ Department of Oral and Maxillofacial Surgery, College of Dentistry, Gangneung-Wonju National University, Gangneung 28644, Republic of Korea. ${ }^{7}$ Department of Oral and Maxillofacial Surgery, College of Dentistry, Gangneung-Wonju National University, 7 Jukhyun-gil, Gangneung 25457, Republic of Korea. ${ }^{8}$ Faculty of Dentistry, Boroujerd Islamic Azad University, Boroujerd, Iran.

Received: 16 March 2020 Accepted: 2 April 2020

\section{Published online: 24 April 2020}

\section{References}

1. Lai CC, Liu YH, Wang CY, Wang YH, Hsueh SC, Yen MY et al Asymptomatic carrier state, acute respiratory disease, and pneumonia due to severe acute respiratory syndrome coronavirus 2 (SARS-CoV-2): facts and myths. J Microbiol Immunol Infect https://doi.org/10.1016/j.jmii.2020.02.012

2. Sexton NR, Smith EC, Blanc H, Vignuzzi M, Peersen OB, Denison MR (2016) Homology-based identification of a mutation in the coronavirus RNAdependent RNA polymerase that confers resistance to multiple mutagens. J Virol 90(16):7415-7428

3. Weiss SR, Navas-Martin S (2005) Coronavirus pathogenesis and the emerging pathogen severe acute respiratory syndrome coronavirus. Microbiol Mol Biol Rev 69(4):635-664

4. Su S, Wong G, Shi W, Liu J, Lai AC, Zhou J et al (2016) Epidemiology, genetic recombination, and pathogenesis of coronaviruses. Trends Microbiol 24(6):490-502

5. Schoeman D, Fielding BC (2019) Coronavirus envelope protein: current knowledge. Virol J 16(1):69

6. World Health Organization (2020) Coronavirus. https://www.who.int/healthtopics/coronavirus. .

7. Habibzadeh P, Stoneman EK (2020) The novel coronavirus: a bird's eye view. Int J Occup Environ Med 11(2):65-71

8. Wevers BA, van der Hoek L (2009) Recently discovered human coronaviruses. Clin Lab Med 29(4):715-724

9. Monto AS (1974) Medical reviews. Coronaviruses. Yale J Biol Med 47(4):234-251

10. Pene F, Merlat A, Vabret A, Rozenberg F, Buzyn A, Dreyfus F et al (2003) Coronavirus 229E-related pneumonia in immunocompromised patients. Clin Infect Dis 37(7):929-932

11. Papa A, Papadimitriou E, de Souza Luna LK, Al Masri M, Souliou E, Eboriadou M et al (2007) Coronaviruses in children, Greece. Emerg Infect Dis 13(6):947-949

12. Cabeça TK, Granato C, Bellei N (2013) Epidemiological and clinical features of human coronavirus infections among different subsets of patients. Influenza Other Respir Viruses 7(6):1040-1047

13. Dijkman R, Jebbink MF, Koekkoek SM, Deijs M, Jónsdóttir HR, Molenkamp R et al (2013) Isolation and characterization of current human coronavirus strains in primary human epithelial cell cultures reveal differences in target cell tropism. J Virol 87(11):6081-6090

14. Peiris J, Lai S, Poon L, Guan Y, Yam L, Lim W et al (2003) Coronavirus as a possible cause of severe acute respiratory syndrome. Lancet 361(9366): 1319-1325

15. Assiri A, Al-Tawfiq JA, Al-Rabeeah AA, Al-Rabiah FA, Al-Hajjar S, Al-Barrak A et al (2013) Epidemiological, demographic, and clinical characteristics of 47 cases of Middle East respiratory syndrome coronavirus disease from Saudi Arabia: a descriptive study. Lancet Infect Dis 13(9):752-761

16. Ricketti A, Vemaleo J (2010) Severe acute respiratory syndrome (SARS). Infect Dis Clin N Am 24(1):175-202
17. Gu J, Gong E, Zhang B, Zheng J, Gao Z, Zhong Y et al (2005) Multiple organ infection and the pathogenesis of SARS. J Exp Med 202(3):415-424

18. Tsang KW, Ho PL, Ooi GC, Yee WK, Wang T, Chan-Yeung M et al (2003) A cluster of cases of severe acute respiratory syndrome in Hong Kong. N Engl J Med 348(20):1977-1985

19. Peiris JSM, Chu C-M, Cheng VC-C, Chan K, Hung I, Poon LL et al (2003) Clinical progression and viral load in a community outbreak of coronavirus-associated SARS pneumonia: a prospective study. Lancet 361(9371):1767-1772

20. Moës E, Vijgen L, Keyaerts E, Zlateva K, Li S, Maes P et al (2005) A novel pancoronavirus RT-PCR assay: frequent detection of human coronavirus NL63 in children hospitalized with respiratory tract infections in Belgium. BMC Infect Dis 5(1):6

21. Bastien N, Anderson K, Hart L, Caeseele PV, Brandt K, Milley D et al (2005) Human coronavirus NL63 infection in Canada. J Infect Dis 191(4):503-506

22. van der Hoek L, Sure K, Ihorst G, Stang A, Pyrc K, Jebbink MF et al (2005) Croup is associated with the novel coronavirus NL63. PLoS Med 2(8):e240

23. Al-Tawfiq JA, Hinedi K, Ghandour J, Khairalla H, Musleh S, Ujayli A et al (2014) Middle East respiratory syndrome coronavirus: a case-control study of hospitalized patients. Clin Infect Dis 59(2):160-165

24. Arabi YM, Arifi AA, Balkhy HH, Najm H, Aldawood AS, Ghabashi A et al (2014) Clinical course and outcomes of critically ill patients with Middle East respiratory syndrome coronavirus infection. Ann Intern Med 160(6):389-397

25. Chen N, Zhou M, Dong X, Qu J, Gong F, Han Y et al (2020) Epidemiological and clinical characteristics of 99 cases of 2019 novel coronavirus pneumonia in Wuhan, China: a descriptive study. Lancet 395(10223):507-513

26. Huang C, Wang Y, Li X, Ren L, Zhao J, Hu Y et al (2020) Clinical features of patients infected with 2019 novel coronavirus in Wuhan, China. Lancet 395(10223):497-506

27. Guan W, Ni Z, Hu Y, Liang W, Ou C, He J et al Clinical characteristics of coronavirus disease 2019 in China. N Engl J Med https://doi.org/10.1056/ NEJMoa2002032

28. Backer JA, Klinkenberg D, Wallinga J Incubation period of 2019 novel coronavirus (2019-nCoV) infections among travellers from Wuhan, China, 20-28 January 2020. Euro Surveill https://doi.org/10.2807/1560-7917.ES.2020. 25.5.2000062

29. Paules Cl, Marston HD, Fauci AS (2020) Coronavirus infections-more than just the common cold. JAMA. 323(8):707-708

30. de Wilde AH, Snijder EJ, Kikkert M, van Hemert MJ (2017) Host factors in coronavirus replication. In: Roles of Host Gene and Non-coding RNA Expression in Virus Infection. Springer, pp 1-42

31. Fields BN, Knipe DM, Howley PM (1996) Fields virology. Lippincott-Raven

32. Sun P, Lu X, Xu C, Sun W, Pan B (2020) Understanding of COVID-19 based on current evidence. J Med Virol

33. Rothe C, Schunk M, Sothmann P, Bretzel G, Froeschl G, Wallrauch C et al (2020) Transmission of 2019-nCoV infection from an asymptomatic contact in Germany. N Engl J Med

34. Chan JF-W, Yuan S, Kok K-H, To KK-W, Chu H, Yang J et al (2020) A familial cluster of pneumonia associated with the 2019 novel coronavirus indicating person-to-person transmission: a study of a family cluster. Lancet 395(10223):514-523

35. Hu D, Zhu C, Ai L, He T, Wang Y, Ye F et al (2018) Genomic characterization and infectivity of a novel SARS-like coronavirus in Chinese bats. Emerg Microbes Infect 7(1):1-10

36. Hu T, Li G, Zuo Y, Zhou X (2007) Risk of hepatitis B virus transmission via dental handpieces and evaluation of an antisuction device for prevention of transmission. Infect Control Hosp Epidemiol 28(1):80-82

37. Peiris JS, Yuen KY, Osterhaus AD, Stöhr K (2003) The severe acute respiratory syndrome. N Engl J Med 349(25):2431-2441

38. Cohen J (2020) Chinese researchers reveal draft genome of virus implicated in Wuhan pneumonia outbreak

39. Organization WH. Laboratory testing of 2019 novel coronavirus ( 2019$\mathrm{nCoV}$ ) in suspected human cases: interim guidance, 17 January 2020. 2020.

40. ADA releases coronavirus handout for dentists based on CDC guidelines: American Dental Association; 2020. Available from: https://www.ada.org/en/ publications/ada-news/2020-archive/february/ada-releases-coronavirushandout-for-dentists-based-on-cdc-guidelines.

41. CDC reminds clinicians to use standard precautions, recommends isolating patients with coronavirus symptoms: American Dental Association; 2020. Available from: https://www.ada.org/en/publications/ada-news/2020archive/february/cdc-recommends-isolating-patients-with-coronavirussymptoms. 
42. Infectious Diseases: 2019 Novel Coronavirus: American Dental Association; 2020. Available from: https://success.ada.org/en/practicemanagement/ patients/infectious-diseases-2019-novel-coronavirus?_ga=2.107628096.39854 $0419.1583353764-477095557.1583353762$.

43. Lu C-W, X-f L, Z-f J (2020) 2019-nCoV transmission through the ocular surface must not be ignored. Lancet

44. To KK-W, Tsang OTY, Chik-Yan Yip C, Chan K-H, Wu T-C, Chan J et al (2020) Consistent detection of 2019 novel coronavirus in saliva. Clin Infect Dis

45. Belser JA, Rota PA, Tumpey TM (2013) Ocular tropism of respiratory viruses. Microbiol Mol Biol Rev 77(1):144-156

46. Holshue ML, DeBolt C, Lindquist S, Lofy KH, Wiesman J, Bruce H et al (2020) First case of 2019 novel coronavirus in the United States. N Engl J Med

47. Peng X, Xu X, Li Y et al (2020) Transmission routes of 2019-nCoV and controls in dental practice. Int J Oral Sci

48. Rodríguez-Morales AJ, MacGregor K, Kanagarajah S, Patel D, Schlagenhauf $P$ (2020) Going global-Travel and the 2019 novel coronavirus. Travel Med Infect Dis:101578

49. Letko MC, Munster V (2020) Functional assessment of cell entry and receptor usage for lineage $B \quad \beta$-coronaviruses, including 2019-nCoV. bioRxiv

50. Zhou P, Yang X-L, Wang X-G, Hu B, Zhang L, Zhang W et al (2020) A pneumonia outbreak associated with a new coronavirus of probable bat origin. Nature.: $1-4$

51. Liu L, Wei Q, Alvarez X, Wang H, Du Y, Zhu H et al (2011) Epithelial cells lining salivary gland ducts are early target cells of severe acute respiratory syndrome coronavirus infection in the upper respiratory tracts of rhesus macaques. J Virol 85(8):4025-4030

52. Kampf G, Todt D, Pfaender S, Steinmann E (2020) Persistence of coronaviruses on inanimate surfaces and its inactivation with biocidal agents. J Hosp Infect

53. Chen J (2020) Pathogenicity and Transmissibility of 2019-nCoV_-A Quick Overview and Comparison with Other Emerging Viruses. Microbes Infect

54. Cleveland JL, Gray SK, Harte JA, Robison VA, Moorman AC, Gooch BF (2016) Transmission of blood-borne pathogens in US dental health care settings: 2016 update. J Am Dent Assoc 147(9):729-738

55. Harrel SK, Molinari J (2004) Aerosols and splatter in dentistry: a brief review of the literature and infection control implications. J Am Dent Assoc 135(4): 429-437

56. Peng X, Xu X, Li Y, Cheng L, Zhou X, Ren B (2020) Transmission routes of 2019-nCoV and controls in dental practice. Int J Oral Sci 12(1):1-6

57. Otter J, Donskey C, Yezli S, Douthwaite S, Goldenberg S, Weber D (2016) Transmission of SARS and MERS coronaviruses and influenza virus in healthcare settings: the possible role of dry surface contamination. J Hosp Infect 92(3):235-250

58. Xian Peng XX, Li Y, Cheng L, Zhou X, Ren B (2020) Transmission routes of 2019-nCoV and controls in dental practice. Int J Oral Sci Vol

59. Committee GOoNH. Office of State Administration of Traditional Chinese Medicine. Notice on the issuance of a program for the diagnosis and treatment of novel coronavirus (2019-nCoV) infected pneumonia (Trial Version 3). 2020. 2020.

60. Samaranayake L, Reid J, Evans D (1989) The efficacy of rubber dam isolation in reducing atmospheric bacterial contamination. ASDC J Dentistry Children 56(6):442-444

61. Samaranayake LP, Peiris M (2004) Severe acute respiratory syndrome and dentistry: a retrospective view. J Am Dent Assoc 135(9):1292-1302

\section{Publisher's Note}

Springer Nature remains neutral with regard to jurisdictional claims in published maps and institutional affiliations.

\section{Submit your manuscript to a SpringerOpen ${ }^{\circ}$ journal and benefit from:}

- Convenient online submission

- Rigorous peer review

- Open access: articles freely available online

- High visibility within the field

- Retaining the copyright to your article

Submit your next manuscript at $\boldsymbol{\nabla}$ springeropen.com 